\title{
Evaluation of Antileishmanial Activity of Selected Brazilian Plants and Identification of the Active Principles
}

\author{
Valdir Cechinel Filho, ${ }^{1,2}$ Christiane Meyre-Silva, ${ }^{2}$ Rivaldo Niero, ${ }^{1,2}$ \\ Luisa Nathália Bolda Mariano, ${ }^{2}$ Fabiana Gomes do Nascimento, ${ }^{1}$ Ingrid Vicente Farias, ${ }^{2}$ \\ Vanessa Fátima Gazoni, ${ }_{1}^{1}$ Bruna dos Santos Silva, ${ }^{2}$ Alberto Giménez, ${ }^{3}$ \\ David Gutierrez-Yapu, ${ }^{3}$ Efrain Salamanca, ${ }^{3}$ and Angela Malheiros ${ }^{1,2}$ \\ ${ }^{1}$ Programa de Pós-Graduação em Ciências Farmacêuticas (PPGCF), Universidade do Vale do Itajaí, Rua Uruguai, 458, Centro, \\ 88302-202 Itajaí, SC, Brazil \\ ${ }^{2}$ Núcleo de Investigações Químico-Farmacêuticas (NIQFAR), Universidade do Vale do Itajaí, Rua Uruguai, 458, Centro, \\ 88302-202 Itajaí, SC, Brazil \\ ${ }^{3}$ Instituto de Investigaciones Fármaco Bioquímicas (IIFB), Universidad Mayor de San Andrés (UMSA), La Paz, Bolivia
}

Correspondence should be addressed to Angela Malheiros; amalheiros@hotmail.com

Received 25 February 2013; Revised 21 April 2013; Accepted 24 May 2013

Academic Editor: Liliana V. Muschietti

Copyright (C) 2013 Valdir Cechinel Filho et al. This is an open access article distributed under the Creative Commons Attribution License, which permits unrestricted use, distribution, and reproduction in any medium, provided the original work is properly cited.

\begin{abstract}
This study evaluated extracts, fractions, and isolated compounds from some selected Brazilian medicinal plants against strains of promastigotes of Leishmania amazonensis and L. brasiliensis in vitro. The cell viability was determined, comparing the results with reference standards. The dichloromethane fractions of the roots, stems, and leaves of Allamanda schottii showed IC $_{50}$ values between 14.0 and $2.0 \mu \mathrm{g} / \mathrm{mL}$. Plumericin was the main active compound, with $\mathrm{IC}_{50}$ of 0.3 and $0.04 \mu \mathrm{g} / \mathrm{mL}$ against the two species of Leishmania analyzed. The hexane extract of Eugenia umbelliflora fruits showed $\mathrm{IC}_{50}$ of 14.3 and $5.7 \mu \mathrm{g} / \mathrm{mL}$ against L. amazonensis and L. brasiliensis, respectively. The methanolic extracts of the seeds of Garcinia achachairu and guttiferone A presented $\mathrm{IC}_{50}$ values of 35.9 and $10.4 \mu \mathrm{g} / \mathrm{mL}$, against L. amazonensis, respectively. The ethanolic extracts of the stem barks of Rapanea ferruginea and the isolated compound, myrsinoic acid B, presented activity against L. brasiliensis with $\mathrm{IC}_{50}$ of 24.1 and $6.1 \mu \mathrm{g} / \mathrm{mL}$. Chloroform fraction of Solanum sisymbriifolium exhibited $\mathrm{IC}_{50}$ of 33.8 and $20.5 \mu \mathrm{g} / \mathrm{mL}$, and cilistol A was the main active principle, with $\mathrm{IC}_{50}$ of 6.6 and $3.1 \mu \mathrm{g} / \mathrm{mL}$ against L. amazonensis and L. brasiliensis, respectively. It is concluded that the analyzed plants are promising as new and effective antiparasitic agents.
\end{abstract}

\section{Introduction}

Leishmania are protozoan parasites responsible for a spectrum of diseases known as leishmaniasis. There are two main forms of leishmaniasis: cutaneous, characterized by skin sores; and visceral, which affects the internal organs (e.g., the spleen, liver, and bone marrow). This disease is classified as a neglected disease and is one of major public health problem, causing significant morbidity and mortality in various countries. Leishmaniasis is considered by the World Health Organization as one of six major infectious diseases, with a high detection rate and ability to produce deformities [1-3].
Currently, the treatment of this disease is based on a limited number of chemotherapeutic agents, which represent high toxicity and cost. The search for new medicinal agents has become extremely important. The higher plants are a very rich source of new and selective substances, with therapeutic potential against these ailments. There are approximately 250.000 plant species worldwide, of which only a fraction has so far been studied. However, much research is needed to identify plants as sources of drugs or their phytoconstituents. The World Health Organization also advocates the use of traditional medicine for the treatment of these tropical diseases [4-6]. 
Our research group participated in an Iberoamerican program (RIBIOFAR/CYTED/CNPq) to search for Brazilian plants with therapeutic potential to treat several diseases, including the so-called neglected diseases. Some species have been previously analyzed with respect to their chemical composition and biological properties. Now we are interested in exploring the potential of the crude plant extracts, semipurified fractions, and chemically defined molecules, in terms of their activity against leishmaniasis. Table 1 gives a list of the plants analyzed, that were selected based on factors related to the discovery of new drugs from the biodiversity, the abundance of these plants, and previous pharmacological studies conducted at our laboratories. The selected plants, Allamanda schottii, Rapanea ferruginea, Eugenia umbelliflora, Garcinia achachairu, and Solanum sisymbrifolium, have exhibited various biological properties, including antiproliferative antinociceptive, anti-inflammatory, antimicrobial, and gastroprotective effects [7-15].

\section{Material and Methods}

2.1. Plant Material. Different parts (leaves, stems, and roots) of Allamanda schottii were collected in the city of Blumenau, in December of 2006. The fruits of Eugenia umbelliflora Berg were collected in June 2008, in the town of Itapema. Rapanea ferruginea, synonymously Myrsine coriacea (Ruiz and Pavon) Mez, was collected in Blumenau in July 2007. Garcinia achachairu was collected in Camboriú, in March 2007. Aerial parts of Solanum sisymbriffolium Lam. were collected in Itapema, in January 2006. All the species were identified or authenticated by Professor Oscar Benigno Iza (Universidade do Vale do Itajaí), and vouchers were deposited at the Barbosa Rodrigues Herbarium (HBR, Itajaí), under numbers HBR 52525 (A. schottii), VC-Filho 50 (E. umbelliflora), HBR 52715 (R. ferruginea), HBR 52637 (M. coriacea), and VC-Filho 037 (S. sisymbriifolium).

2.2. Preparation of Extracts and Fractions. The dried vegetal material (100 g) of each part (roots, stems, and leaves) of A. schottii was macerated with $95 \%$ ethanol at room temperature, for seven days. Solvent removal was carried out under reduced pressure at temperatures below $45^{\circ} \mathrm{C}$, until the desired concentrations were achieved, in order to obtain the ethanolic extracts. Part of each extract was dissolved separately in methanol: water $(90: 10)$ and successively partitioned with hexane, dichloromethane, and ethyl acetate to obtain the respective fractions, after the removal of solvents. The samples were stored under refrigeration and protected from light until analysis.

The fruits of E. umbelliflora were dried under air circulation $\left(37^{\circ} \mathrm{C}\right)$ for 2 days and powdered using a knife grinder. The dried fruits $(570 \mathrm{~g})$ were extracted twice by maceration with $n$-hexane for five days. Next, solvent was removed under vacuum to yield a dry residue of $2.62 \%$ hexane extract. The fruits were then reextracted using dichloromethane and methanol, following the methods described above. The separate extracts were submitted to concentration to obtain dichloromethane and methanolic extract 1 with yields of
$1.16 \%$ and $4.47 \%$, respectively. The methanolic extract 2 was obtained by extracting the dried fruits with methanol at room temperature for seven days.

The dried material $100 \mathrm{~g}$ of each part (leaves, stem barks and fruits) of $R$. ferruginea was macerated with $95 \%$ ethanol at room temperature, for seven days. Solvent removal was carried out under reduced pressure at temperatures below $45^{\circ} \mathrm{C}$, until the desired concentrations were achieved, in order to obtain ethanolic extracts with yields of $16 \%, 15 \%$, and $13 \%$ from leaves, stem, and fruits, respectively. The chloroform extract was obtained by the stem barks and is described in Hess et al. [9].

The air-dried and powdered seeds, leaves and branches ( $250 \mathrm{~g}$ each) of $\mathrm{G}$. achachairu were separately extracted at room temperature with methanol for seven days. The macerated material was filtered and concentrated under reduced pressure, yielding $9.01 \mathrm{~g}(3.6 \%), 15.0 \mathrm{~g}$ (6\%), and $12.0 \mathrm{~g}(4.8 \%)$ of crude methanolic extract, respectively.

The powdered leaves, and stem (680.0 g) of S. sisymbriifolium were extracted with $\mathrm{MeOH}$ for ten days. The concentrated methanolic extract was diluted with a water: methanol mixture $(9: 1,300 \mathrm{~mL})$ and extracted with hexane $(11.5 \mathrm{~g}$; $1.70 \%)$, chloroform (11.2 g; 1.64\%), and ethyl acetate (1.18 g; $0.17 \%)$.

\subsection{Isolation and Identification of Components.}

A. schottii. The ethanolic extract of A. schottii stems (15.1 g) was chromatographed in a silica-gel column with a hexane: ethylacetate: ethanol gradient. The fraction eluted with n-hexane: ethyl acetate $7: 3$ yielded plumericin $(15.2 \mathrm{mg})$. Elution with a hexane : ethyl acetate ratio of $6.5: 3.5$ yielded ursolic acid $(62.4 \mathrm{mg})$. The fraction eluted with ethyl acetate: ethanol 8:2 yielded plumieride (39.4 mg) as described previously by Schmidt et al. [7] and Malheiros et al. [29].

R. ferruginea. The $\mathrm{CHCl}_{3}$ extract of $\mathrm{R}$. ferruginea (63.4 g) was subjected to column chromatography packed with silica gel 60-230 mesh and eluted with hexane gradually enriched in ethyl acetate. The fraction eluted with $40 \%$ ethyl acetate in hexane provides impure myrsinoic acid $\mathrm{B}$. This fraction $(8.5 \mathrm{~g})$ was chromatographed in a silica-gel column with hexane : ethyl acetate to provide pure myrsinoic acid B ( $4.3 \mathrm{~g})$ as described previously by Baccarin et al. [30].

E. umbelliflora. The complete procedure used to obtain the compound isolated from E. umbelliflora fruits, the meroterpenoid Eugenial A, was described previously by Faqueti et al. [11].

G. achachairu. The methanolic extract of the seeds $(5.0 \mathrm{~g})$ was chromatographed on a silica-gel column $(0.063-0.20 \mathrm{~mm}$, $84.0 \mathrm{~g}, 2.5 \times 50 \mathrm{~cm}$, Merck) and eluted with a gradient of $\mathrm{CHCl}_{3}-\mathrm{MeOH}(100->0)$ yielding guttiferone $\mathrm{A}$ as described previously by Dal Molin et al. [13].

S. sisymbriffolium. The chloroform fraction was purified by CC on silica gel, yielding Cilistol A (60.0 mg) and cilistadiol 
TABLE 1: Traditional uses of the selected Brazilian medicinal plants and previous pharmacological studies.

\begin{tabular}{|c|c|c|c|}
\hline Species & Popular use & Biological studies & Reference \\
\hline A. schotii & $\begin{array}{l}\text { Latex: used as scabicide and in louse control } \\
\text { The infusion of flowers is purgative and } \\
\text { antihelminthic } \\
\text { The stems are used against hepatic tumors }\end{array}$ & antiproliferative effect leukemic cells & {$[7,16-20]$} \\
\hline E. umbelliflora & $\begin{array}{c}\text { Fruits and leaves used to treat various ailments such } \\
\text { as infections, inflammation, and diabetes }\end{array}$ & $\begin{array}{l}\text { Antimicrobial, gastroprotective, } \\
\text { antifungal }\end{array}$ & {$[10,21-23]$} \\
\hline G. achachairu & $\begin{array}{c}\text { Rheumatism, inflammation, pain, and gastric } \\
\text { disorders }\end{array}$ & $\begin{array}{l}\text { Low genotoxicity, } \\
\text { gastroprotective, and } \\
\text { antinociceptive activity }\end{array}$ & {$[13-15,24]$} \\
\hline R. ferruginea & $\begin{array}{c}\text { The leaves or the bark prepared as a tea is indicated } \\
\text { as a diuretic, to combat diseases of the urinary tract } \\
\text { and also is a good cleanser. It is used too for itching, } \\
\text { rashes, hives, eczema, rheumatism, and diseases of } \\
\text { the liver }\end{array}$ & $\begin{array}{l}\text { Anti-inflammatory and } \\
\text { analgesic activity }\end{array}$ & {$[9,12,25]$} \\
\hline S. sisymbriifolium & Diarrhea, respiratory and urinary infections & Hypotensive and molluscicidal activity & {$[26-28]$} \\
\hline
\end{tabular}

(25.0 $\mathrm{mg}$ ) as described previously by Niero et al. [8]. The molecular structures of isolated compounds are presented in Figure 1.

\subsection{Leishmanicidal Activity}

2.4.1. Promastigotes of Leishmania amazonensis Clone 1. AML (MHOM/BR/76/LTB-012) and Leishmania braziliensis (M2904 C192 RJA) obtained from in vitro cultures of IIFB $(20 \mu \mathrm{L})$ were fixed with glutaraldehyde $(5 \%, 180 \mu \mathrm{L})$ and counted in a Neubauer chamber. The population was adapted to $3 \times 10^{6}$ parasites $/ \mathrm{mL}$ with Schneider medium $(\mathrm{pH}=6.8)$ and Fetal Bovine Serum (10\%), distributed (100 $\mu \mathrm{L} /$ well) in 96-microwell plates. Solutions of the samples, at different concentrations, were added $(100 \mu \mathrm{L})$. DMSO $(1 \%)$ and Amphotericin B $(0.5 \mu \mathrm{g} / \mathrm{mL})$ were used as parasite growth control. Each test was performed in triplicate and the plates were incubated for 72 hours at $26^{\circ} \mathrm{C}$.

To each well of the plate was added $(50 \mu \mathrm{L} /$ well $)$ a solution of XTT $(1 \mathrm{mg} / \mathrm{mL})$ in phosphate buffer $\left(\mathrm{pH} 7.0,37^{\circ} \mathrm{C}\right)$ with PMS (Sigma-Aldrich, $0.06 \mathrm{mg} / \mathrm{mL}$ ), which was incubated for $4 \mathrm{~h}$ at $26^{\circ} \mathrm{C}$. The plates were read on a computer Stat Fax (Model 2100 Series-Plate Reader) at $450 \mathrm{~nm}$. The $\mathrm{IC}_{50}$ values of $50 \%$ inhibitory concentration of parasites were calculated using Microsoft Excel 2000 [31].

2.5. Statistical Analysis of Data. The samples were analyzed in replicates with $n=4$, using two methods of viability assessment (XTT and Neutral Red). The data are mean \pm stand error, and statistical differences were determined by the one-way ANOVA followed by Tukey-Kiover $\left({ }^{*} P<0.05\right.$, ${ }^{* *} P<0.01$ and $\left.{ }^{* * *} P<0.001\right)$.

\section{Results and Discussion}

In this work we tested extracts, fractions, and compounds of five Brazilian medicinal plants to determine their in vitro antiparasitic effect against promastigotes of L. amazonensis and L. brasiliensis. For the initial screening, extracts with $\mathrm{IC}_{50}$ less than $100 \mu \mathrm{g} / \mathrm{mL}$ were considered active. The results of the minimal inhibitory concentrations are shown in Tables 2 and 3.

The ethanolic extracts from different parts of $A$. schottii (roots, stems, and leaves) exhibited pronounced leishmanicidal activity (Table 2 ). The best results were obtained from the root extracts with $\mathrm{IC}_{50}$ of $43.8 \mu \mathrm{g} / \mathrm{mL}$ for L. amazonensis and $8.5 \mu \mathrm{g} / \mathrm{mL}$ for $L$. brasiliensis. The extracts were submitted to partition with hexane, dichloromethane, and ethyl acetate. The activity was concentrated in the dichloromethane fraction for all extracts with $\mathrm{IC}_{50}$ of 2.1 to $13.4 \mu \mathrm{g} / \mathrm{mL}$. The best activity was observed in the dichloromethane fraction of the roots with $\mathrm{IC}_{50}$ of $2.1 \mu \mathrm{g} / \mathrm{mL}$ for L. amazonensis and $8.8 \mu \mathrm{g} / \mathrm{mL}$ for $L$. brasiliensis, suggesting that the iridoid plumericin and the triterpene ursolic acid are the main active principles. These compounds were isolated from the ethanolic extract of the stems and detected in all the dichloromethane fractions by thin layer chromatography. Plumericin presented $\mathrm{IC}_{50}$ of $0.3 \mu \mathrm{g} / \mathrm{mL}(0.98 \mu \mathrm{M})$ for $L$. amazonensis and $0.04 \mu \mathrm{g} / \mathrm{mL}(0.13 \mu \mathrm{M})$ for L. brasiliensis. Ursolic acid was active against the two species evaluated with $\mathrm{IC}_{50}$ of $66.1 \mu \mathrm{g} / \mathrm{mL}$ and $8.3 \mu \mathrm{g} / \mathrm{mL}$ for L. amazonensis and L. brasiliensis, respectively. Amphotericin B, used as positive control, exhibited activity with $\mathrm{IC}_{50}$ of $0.6 \mu \mathrm{g} / \mathrm{mL}$ and $0.7 \mu \mathrm{g} / \mathrm{mL}$, respectively, for the two species evaluated (Table 3). Another evaluated iridoid was plumieride, a glycoside iridoid, which was detected in all the ethyl acetate fractions, presenting $\mathrm{IC}_{50}$ of $21.3 \mu \mathrm{g} / \mathrm{mL}$ for L. brasiliensis. This compound may be responsible for the activity observed in ethyl acetate fractions of different parts of this plant.

The Apocynaceae family is as a rich source of species with antileishmanicidal activity and for some species, plumericin is the main active compound. This compound, previously isolated from Himatanthus sucuuba, presented $\mathrm{IC}_{50}$ values of 0.9 and $1.0 \mu \mathrm{M}$ against promastigote and amastigote forms of L. amazonensis [32] and $\mathrm{IC}_{50}$ of $3.17 \pm 0.12$ and $1.41 \pm$ $0.03 \mu \mathrm{M}$ against promastigotes and amastigotes of $L$. donovani, respectively [33]. 
<smiles>C/C=C1/C(=O)O[C@]23C=C[C@H]4C(C(=O)OC)=CO[C@H](O)[C@H]4[C@H]1[C@H]2O3</smiles>

Plumericin<smiles>COC(=O)C1=CO[C@H](OC(O)C(O)C2COCC(O)C(O)C2O)C2C1C=C[C@]21C=C(C(C)O)C(=O)O1</smiles>

Plumieride<smiles>CC1CC[C@]2(C(=O)O)CC[C@]3(C)C(=CCC4[C@@]5(C)CC[C@@H](O)C(C)(C)C5CC[C@]43C)C2C1C</smiles>

Ursolic acid<smiles>CC(C)=CCCC(C)(O)C1Cc2cc(C(=O)O)cc(CC=C(C)C)c2O1</smiles>

Myrsinoic acid B<smiles>CCCC(=O)c1c(O)c(C=O)c2c(c1O)C[C@@H]1C[C@@H](C(C)C)C=C[C@@H]1O2</smiles>

Eugenial A<smiles>C[C@H](C1C[C@](C)(O)[C@@](C)(O)[C@@H](O)O1)[C@]1(O)CCC2C3CC=C4CC=CC(=O)[C@@]4(C)C3CC[C@]21C</smiles>

Cilistol A<smiles>CC(C)=CCC[C@@H]1C[C@@]2(CC=C(C)C)C(=O)C(O)=C(C(=O)c3ccc(O)c(O)c3)C(=O)[C@@]2(CC=C(C)C)[C@@]1(C)CC=C(C)C</smiles>

Guttiferone A

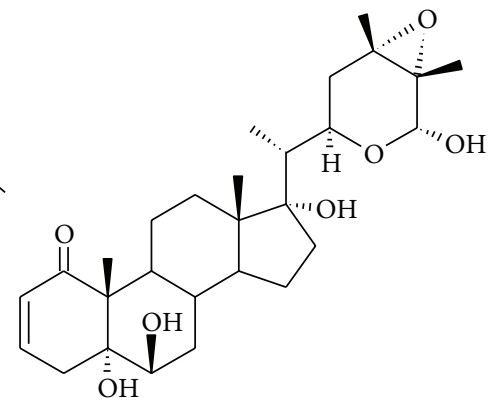

Cilistadiol

FIGURE 1: Molecular structure of the isolated compounds from analyzed plants.

On the other hand, ursolic acid was isolated as an active compound from extracts of Baccharis dracunculifolia (Asteraceae) against Leishmania donovani with $\mathrm{IC}_{50}$ of $3.7 \mu \mathrm{g} / \mathrm{mL}$ [34]. Our results, together with those reported in the literature, suggest that the compounds found in Allamanda genus are promising antileishmanial agents.

The antiparasitic investigation against promastigotes of $L$. amazonensis and L. brasiliensis with respect to E. umbelliflora fruits indicated that the hexane extract was the most active with $\mathrm{IC}_{50}$ of $14.3 \pm 0.86$ and $5.7 \pm 0.92 \mu \mathrm{g} / \mathrm{mL}$, respectively. When the fruits were directly submitted to methanol extraction, activity was observed with $\mathrm{IC}_{50}$ of $12.5 \pm 0.5$ and $7.8 \pm 0.4 \mu \mathrm{g} / \mathrm{mL}$ against L. amazonensis and L. brasiliensis, respectively. Despite reports in the ethnobotanical literature on the medicinal uses of Eugenia species to treat some diseases, there have been few scientific studies that validate their antileishmanial activity. Previous studies with Eugenia genus have suggested that terpenic compounds found in the essential oil may have potential anti-leishmanial activity [35].

Continuing our screening program in the search for bioactive molecules from Brazilian plants, we have investigated G. achachairu for its leishmanicidal activity. Thus, the methanolic extract, some fractions, and isolated compounds were evaluated. As can be seen in Table 2, the methanolic extract of the seeds, leaves, and branches obtained from $G$. achachairu exhibited $\mathrm{IC}_{50}$ values of 35.9 and $100 \mu \mathrm{g} / \mathrm{mL}$ in promastigote forms of L. amazonensis and 28.2, 100, and $81.6 \mu \mathrm{g} / \mathrm{mL}$ against promastigote of L. brasiliensis, respectively. The most bioactive extract (from the seeds) was chromatographed on a silica-gel column yielding guttiferone $\mathrm{A}$ as the main constituent. This compound, after evaluation in promastigote forms of L. amazonensis and L. brasiliensis 
TABLE 2: In vitro leishmanicidal activity of extracts on promastigotes of Leishmania amazonensis and L. brasiliensis.

\begin{tabular}{|c|c|c|c|}
\hline Species & Sample & L. amazonensis $\mathrm{IC}_{50}(\mu \mathrm{g} / \mathrm{mL})^{\mathrm{a}}$ & L. brasiliensis $\mathrm{IC}_{50}(\mu \mathrm{g} / \mathrm{mL})^{\mathrm{a}}$ \\
\hline \multirow{12}{*}{ A. schottii } & Ethanolic extract roots & $43.8 \pm 1.13$ & $8.5 \pm 0.47$ \\
\hline & Hexane fraction & $49.4 \pm 2.27$ & $48.6 \pm 1.23$ \\
\hline & Dichloromethane fraction & $2.1 \pm 0.25$ & $8.8 \pm 0.37$ \\
\hline & Ethyl acetate fraction & $85.6 \pm 3.57$ & $67.8 \pm 0.14$ \\
\hline & Ethanolic extract stems & $>100$ & $39.0 \pm 0.56$ \\
\hline & Hexane fraction & $>100$ & $17.8 \pm 1.83$ \\
\hline & Dichloromethane fraction & $13.6 \pm 3.80$ & $8.2 \pm 0.07$ \\
\hline & Ethyl acetate fraction & $>100$ & $47.9 \pm 3.60$ \\
\hline & Ethanolic extract leaves & $63.8 \pm 1.10$ & $65.7 \pm 6.71$ \\
\hline & Hexane fraction & $>100$ & $36.7 \pm 6.80$ \\
\hline & Dichloromethane fraction & $13.4 \pm 1.27$ & $8.9 \pm 0.63$ \\
\hline & Ethyl acetate fraction & $>100$ & $32.9 \pm 6.10$ \\
\hline \multirow{5}{*}{ E. umbelliflora } & Hexane extract fruits & $14.3 \pm 0.86$ & $5.7 \pm 0.92$ \\
\hline & Dichloromethane extract fruits & $37.0 \pm 1.02$ & $20.7 \pm 0.05$ \\
\hline & Ethyl acetate extract fruits & $27.2 \pm 4.80$ & $37.6 \pm 0.44$ \\
\hline & Methanolic extract fruits 1 & $>100$ & $>100$ \\
\hline & Methanolic extract fruits 2 & $12.5 \pm 0.50$ & $7.8 \pm 0.40$ \\
\hline \multirow{3}{*}{ G. achachairu } & Methanolic extract seeds & $35.9 \pm 0.52$ & $28.2 \pm 0.35$ \\
\hline & Methanolic extract leaves & $>100$ & $>100$ \\
\hline & Methanolic extract branches & $>100$ & $81.6 \pm 0.25$ \\
\hline \multirow{3}{*}{ R. feruginea } & Ethanolic extract fruits & $>100$ & $>100$ \\
\hline & Ethanolic extract leaves & $>100$ & $>100$ \\
\hline & Ethanolic extract stem barks & $66.4 \pm 2.68$ & $24.9 \pm 1.79$ \\
\hline \multirow{3}{*}{ S. sisymbrifolium } & Hexane fraction & $>100$ & $74.3 \pm 0.22$ \\
\hline & Chloroform fraction & $33.8 \pm 0.81$ & $20.5 \pm 0.76$ \\
\hline & Ethyl acetate fraction & $>100$ & $>100$ \\
\hline \multirow{2}{*}{ Positive control } & Catetanol & $21.1 \pm 4.27$ & $21.4 \pm 5.53$ \\
\hline & Amphotericin B & $0.6 \pm 0.36$ & $0.7 \pm 0.36$ \\
\hline
\end{tabular}

${ }^{\mathrm{a}}$ Data are expressed as mean \pm standard deviation of three determinations.

TABLE 3: In vitro leishmanicidal activity of isolated compounds on promastigotes of Leishmania amazonensis and L. brasiliensis.

\begin{tabular}{|c|c|c|c|}
\hline Species & Isolated compounds & L. amazonensis $\mathrm{IC}_{50}(\mu \mathrm{g} / \mathrm{mL})^{\mathrm{a}}$ & L. brasiliensis $\mathrm{IC}_{50}(\mu \mathrm{g} / \mathrm{mL})^{\mathrm{a}}$ \\
\hline \multirow{3}{*}{ A. schottii } & Plumericin & $0.3 \pm 0.07$ & $0.04 \pm 0.007$ \\
\hline & Plumieride & $>100$ & $21.3 \pm 2.80$ \\
\hline & Ursolic acid & $66.1 \pm 1.22$ & $8.3 \pm 0.84$ \\
\hline R. ferruginea & Myrsinoic acid B & $24.1 \pm 0.52$ & $6.1 \pm 0.24$ \\
\hline E. umbelliflora & Eugenial A & $>100$ & $53.8 \pm 1.71$ \\
\hline G. achachairu & Guttiferone A & $10.4 \pm 0.50$ & $18.4 \pm 0.20$ \\
\hline \multirow{2}{*}{ S. sisymbriifolium } & Cilistol A & $6.6 \pm 0.22$ & $3.1 \pm 0.25$ \\
\hline & Cilistadiol & $>100$ & $59.8 \pm 0.32$ \\
\hline \multirow{2}{*}{ Positive control } & Catetanol & $21.1 \pm 4.27$ & $21.4 \pm 5.53$ \\
\hline & Amphotericin B & $0.6 \pm 0.36$ & $0.7 \pm 0.36$ \\
\hline
\end{tabular}

${ }^{\mathrm{a}}$ Data are expressed as mean \pm standard deviation of three determinations.

(Table 3), showed a significant activity with $\mathrm{IC}_{50}$ values of 10.4 and $18.4 \mu \mathrm{g} / \mathrm{mL}$.

The ethanolic extracts of fruits, leaves, and stem bark of $R$. ferruginea were evaluated against promastigotes of $L$. amazonensis and L. brasiliensis. Only the extracts of the stem bark presented activity, with $\mathrm{IC}_{50}$ of $66.4 \mu \mathrm{g} / \mathrm{mL}$ for
L. amazonensis and $24.9 \mu \mathrm{g} / \mathrm{mL}$ for L. brasiliensis. In this extract, the main compound was a prenylated benzoic acid derivative known as myrsinoic acid B, with $\mathrm{IC}_{50}$ of $24.1 \mu \mathrm{g} / \mathrm{mL}$ for $L$. amazonensis and $6.1 \mu \mathrm{g} / \mathrm{mL}$ for $L$. brasiliensis. These extracts were previously evaluated by high performance liquid chromatography, and myrsinoic acid B was confirmed 
as the main compound in the stem bark extract. In leaves and fruits, it is present in lower concentrations [30]. It is interesting to note that species from the Rapanea genus are not known for their leishmanicidal activity, our studies being the first to suggest its importance as a possible source of antileishmanicidal agents.

According to the literature data, some biological activities of natural products, such as antimicrobial and trypanocidal products, are associated with their prenylated compounds, which may be increased by increasing the number of prenyl residues attached by an increase in lipophilicity [36, 37]. Thus, considering that guttiferone $\mathrm{A}$ and myrsinoic acid $\mathrm{B}$ are prenylated compounds, the activity observed for these compounds could be explained.

Regarding S. sisymbriifolium, we have observed an important antileishmanial activity. As shown in Table 2, the chloroform fraction exhibited $\mathrm{IC}_{50}$ values of $33.8 \mu \mathrm{g} / \mathrm{mL}$ against promastigote forms of L. amazonensis. On the other hand, the hexane and ethyl acetate fractions exhibited $\mathrm{IC}_{50}$ values of $100 \mu \mathrm{g} / \mathrm{mL}$. In relation to the promastigote forms of $L$. brasiliensis, both hexane and chloroform fractions presented $\mathrm{IC}_{50}$ values of 74.3 and $20.50 \mu \mathrm{g} / \mathrm{mL}$, respectively. However, the ethyl acetate fractions exhibited an $\mathrm{IC}_{50}$ value of $100 \mu \mathrm{g} / \mathrm{mL}$, suggesting that the less polar compounds are responsible for the observed activity. This can be confirmed by the activity of two compounds isolated from the chloroform fractions and identified as cilistol A and cilistadiol (Figure 1). These compounds exhibited $\mathrm{IC}_{50}$ values of 6.60 and more than $100 \mu \mathrm{g} / \mathrm{mL}$ against the promastigote forms of L. amazonensis and $\mathrm{IC}_{50}$ values of 3.1 and $59.8 \mu \mathrm{g} / \mathrm{mL}$ for the promastigote forms of L. brasiliensis, respectively (Table 3 ).

\section{Conclusions}

Our results, together with those reported in the literature, strongly suggest that Allamanda schottii, Rapanea ferruginea, Eugenia umbelliflora, Garcinia achachairu, and Solanum sisymbriffolium and, in particular, the compounds plumericin, plumieride, ursolic acid, guttiferone A, cilistol A, and cilistadiol could be promising for the treatment of leishmaniasis caused by protozoans, demanding a search for new chemotherapeutic agents. However, further studies (in vitro and in vivo) need to be carried out, in order to understand the mechanisms of action and to evaluate the toxicity, searching for a clinical use for these bioactive compounds.

\section{Conflict of Interests}

The authors declare that they have no conflict of interests and no financial connection to any commercial entity mentioned in the paper.

\section{Acknowledgments}

The authors thank the Conselho Nacional de Desenvolvimento Científico e Tecnológico (CNPq), Fundação de Apoio à Pesquisa Científica e Tecnológica do Estado de Santa Catarina (FAPESC), Programa Iberoamericano de Ciência y
Tecnologia para el Desarrollo (CYTED)-Red 0284 RIBIOFAR, and the University of Vale do Itajaí (UNIVALI) for their financial support.

\section{References}

[1] L. A. Calderon, I. Silva-Jardim, J. P. Zuliani et al., "Amazonian biodiversity: a view of drug development for leishmaniasis and malaria," Journal of the Brazilian Chemical Society, vol. 20, no. 6, pp. 1011-1023, 2009.

[2] P. Mitropoulos, P. Konidas, and M. Durkin-Konidas, "New World cutaneous leishmaniasis: updated review of current and future diagnosis and treatment," Journal of the American Academy of Dermatology, vol. 63, no. 2, pp. 309-322, 2010.

[3] World Health Organization, "Control of the leishmaniases," World Health Organization Technical Report Series 949.186, 2010.

[4] R. Sen and M. Chatterjee, "Plant derived therapeutics for the treatment of Leishmaniasis," Phytomedicine, vol. 18, no. 12, pp. 1056-1069, 2011.

[5] L. F. Oliveira, A. O. Schubach, M. M. Martins et al., "Systematic review of the adverse effects of cutaneous leishmaniasis treatment in the New World," Acta Tropica, vol. 118, no. 2, pp. 87-96, 2011.

[6] T. S. Tiuman, A. O. Santos, T. Ueda-Nakamura, B. P. D. Filho, and C. V. Nakamura, "Recent advances in leishmaniasis treatment," International Journal of Infectious Diseases, vol. 15, no. 8, pp. e525-e532, 2011.

[7] D. F. N. Schmidt, R. A. Yunes, E. J. Schaab et al., "Evaluation of the anti-proliferative effect the extracts of Allamanda blanchetti and A. Schottii on the growth of leukemic and endothelial cells," Journal of Pharmaceutical Science, vol. 9, pp. 200-208, 2006.

[8] R. Niero, I. T. Da Silva, G. C. Tonial et al., "Cilistepoxide and cilistadiol, two new withanolides from Solanum sisymbiifolium," Natural Product Research, vol. 20, no. 13, pp. 1164-1168, 2006.

[9] S. Hess, C. Padoani, L. C. Scorteganha et al., "Assessment of mechanisms involved in antinociception caused by myrsinoic acid B," Biological and Pharmaceutical Bulletin, vol. 33, no. 2, pp. 209-215, 2010.

[10] C. Meyre-Silva, C. M. Petry, T. E. Berté et al., "Phytochemical analyses and gastroprotective effects of Eugenia umbelliflora (Myrtaceae) on experimental gastric ulcers in rates," Natural Product Communications, vol. 4, no. 7, pp. 911-916, 2009.

[11] L. G. Faqueti, C. M. Petry, C. Meyre-Silva et al., "Eugloballike compounds from the genus Eugenia," Natural Products Research, vol. 27, no. 1, 2013.

[12] C. D. S. Antonialli, G. F. da Silva, L. W. Rocha et al., "Antihyperalgesic effects of myrsinoic acid $\mathrm{B}$ in pain-like behavior induced by inflammatory and neuropathic pain models in mice," Anesthesia and Analgesia, vol. 115, no. 2, pp. 461-469, 2012.

[13] M. M. Dal Molin, S. Silva, D. R. Alves et al., "Phytochemical analysis and antinociceptive properties of the seeds of Garcinia achachairu," Archives of Pharmacal Research, vol. 35, pp. 623631, 2012.

[14] S. Silva, M. M. Dal Molin, V. Cechinel-Filho, R. Niero, and S. G. Andrade, "Gastroprotective effects of extracts and guttiferone A isolated from Garcinia achachairu Rusby (Clusiaceae) against experimentally induced gastric lesions in mice," NaunynSchmiedeberg's Archives of Pharmacology, vol. 365, pp. 1103-1109, 2012. 
[15] E. S. Marques, S. Silva, R. Niero et al., "Genotoxicity assessment of Garcinia achachairu Rusby (Clusiaceae) extract in mammalian cells in vivo," Journal of Ethnopharmacology, vol. 142, pp. 362-366, 2012.

[16] C. Correa-JR, L. C. Ming, and M. C. Scheffer, Cultivo de Plantas Medicinais, Condimentares e Aromáticas, FUNEP, Jaboticabal, Brazil, 2nd edition, 1984.

[17] H. Lorenzi and F. J. A. Matos, Plantas Medicinais do Brasil: Nativas e Exóticas, Instituto Plantarum, Nova Odessa, Brazil, 2002.

[18] F. Moreira, As Plantas Que Curam, Hemus, São Paulo, 1985.

[19] S. S. Rahayu, "Allamanda cathartica L. Plant Resources of South-East Asia," in Medicinal and Poisonous Plants, J. L. Valkenburg and N. Bunyapraphatsara, Eds., vol. 12, Backhuys Publisher, Leiden, The Netherlands, 2001.

[20] R. K. Lopes, M. R. Ritter, and S. M. K. Rates, "Revisão das atividades biológicas e toxicidade das plantas ornamentais mais utilizadas no Rio Grande do Sul, Brasil," Revista Brasileira De Biociências, vol. 7, pp. 305-315, 2009.

[21] R. ReitzMyrtáceas, Eugenia: FIC, I Parte, Fasc. Mirt. Flora Ilustrada Catarinense, Legrand and Klein, Itajaí, Brazil, 1969.

[22] K. E. Machado, V. Cechinel Filho, M. L. Tessarolo, R. Mallmann, C. Meyre-Silva, and A. Bella Cruz, "Potent antibacterial activity of Eugenia umbelliflora," Pharmaceutical Biology, vol. 43, no. 7, pp. 636-639, 2005.

[23] K. E. Machado, V. Cechinel Filho, R. C. B. Cruz, C. Meyre-Silva, and A. Bella Cruz, "Antifungal activity of Eugenia umbelliflora against dermatophytes," Natural Product Communications, vol. 4, no. 9, pp. 1181-1184, 2009.

[24] W. Barbosa, E. A. Chagas, L. Martins, R. Pio, M. L. S. Tucci, and F. A. Artioli, "Germinação de sementes e desenvolvimento inicial de plântulas de achachairu," Revista Brasileira De Fruticultura, vol. 30, pp. 263-266, 2008.

[25] H. Lorenzi, Árvores Brasileiras, Plantarum, Nova Odessa, Brazil, 1992.

[26] D. A. Ibarrola, M. H. Ibarrola, C. Vera, Y. Montalbetti, and E. A. Ferro, "Hypotensive effect of crude root extract of Solanum sisymbriifolium (Solanaceae) in normo- and hypertensive rats," Journal of Ethnopharmacology, vol. 54, no. 1, pp. 7-12, 1996.

[27] D. A. Ibarrola, M. C. Hellión-Ibarrola, Y. Montalbetti et al., "Antihypertensive effect of nuatigenin-3-O- $\beta$-chacotriose from Solanum sisymbriifolium Lam. (Solanaceae) (ñuatî pytâ) in experimentally hypertensive (ARH + DOCA) rats under chronic administration," Phytomedicine, vol. 18, no. 8-9, pp. 634-640, 2011.

[28] J.-J. M. Bagalwa, L. Voutquenne-Nazabadioko, C. Sayagh, and A. S. Bashwira, "Evaluation of the biological activity of the molluscicidal fraction of Solanum sisymbriifolium against non target organisms," Fitoterapia, vol. 81, no. 7, pp. 767-771, 2010.

[29] A. Malheiros, I. T. A. Schuquel, and G. J. Vidotti, "Atribuição inequívoca de deslocamentos químicos de $\mathrm{RMN}{ }^{1} \mathrm{He}{ }^{13} \mathrm{C}$ de plumierideo isolado de Allamandacathartica," Quimica Nova, vol. 20, pp. 457-459, 1997.

[30] T. Baccarin, R. S. Muceneeki, T. M. B. Bresolin, R. A. Yunes, Â. Malheiros, and R. M. Lucinda-Silva, "Development and validation of an HPLC-PDA method for the determination of myrsinoic acid B in the extracts of Rapanea ferruginea Mez," Talanta, vol. 85, no. 2, pp. 1221-1224, 2011.

[31] E. Salamanca-Capusiri, G. R. Pinell, J. C. T. Huallpara, and A. G. Turba, "Método colorimétrico-XTT: como evaluacian de alto rendimiento de sustancias con actividad leishmanicida," BIOFARBO, vol. 16, pp. 21-27, 2008.
[32] D. Castillo, J. Arevalo, F. Herrera et al., "Spirolactone iridoids might be responsible for the antileishmanial activity of a Peruvian traditional remedy made with Himatanthus sucuuba (Apocynaceae)," Journal of Ethnopharmacology, vol. 112, no. 2, pp. 410-414, 2007.

[33] U. Sharma, D. Singh, P. Kumar, M. P. Dobhal, and S. Singh, "Antiparasitic activity of plumericin \& isoplumericin isolated from Plumeria bicolor against Leishmania donovani," Indian Journal of Medical Research, vol. 134, no. 11, pp. 709-716, 2011.

[34] A. A. D. S. Filho, D. O. Resende, M. J. Fukui et al., "In vitro antileishmanial, antiplasmodial and cytotoxic activities of phenolics and triterpenoids from Baccharis dracunculifolia D. C. (Asteraceae)," Fitoterapia, vol. 80, no. 8, pp. 478-482, 2009.

[35] K. A. F. Rodrigues, L. V. Amorim, J. M. G. Oliveira et al., "Eugenia uniflora L. essential oil as a potential anti-Leishmania agent: effects on Leishmania amazonensis and possible mechanisms of action," Evidence-Based Complementary and Alternative Medicine, vol. 2013, Article ID 279726, 10 pages, 2013.

[36] H. Aga, T. Shibuya, T. Sugimoto, M. Kurimoto, and S. H. Nakajima, "Isolation and identification of antimicrobial compounds in Brazilian propolis," Bioscience Biotechnology and Biochemistry, vol. 58, pp. 945-946, 1994.

[37] I. O. Pereira, M. J. Marques, A. L. R. Pavan et al., "Leishmanicidal activity of benzophenones and extracts from Garcinia brasiliensis Mart. fruits," Phytomedicine, vol. 17, no. 5, pp. 339345, 2010. 


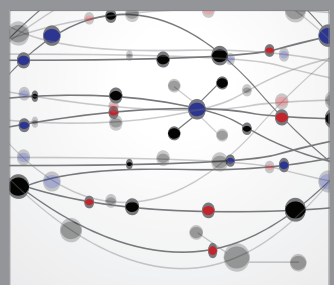

The Scientific World Journal
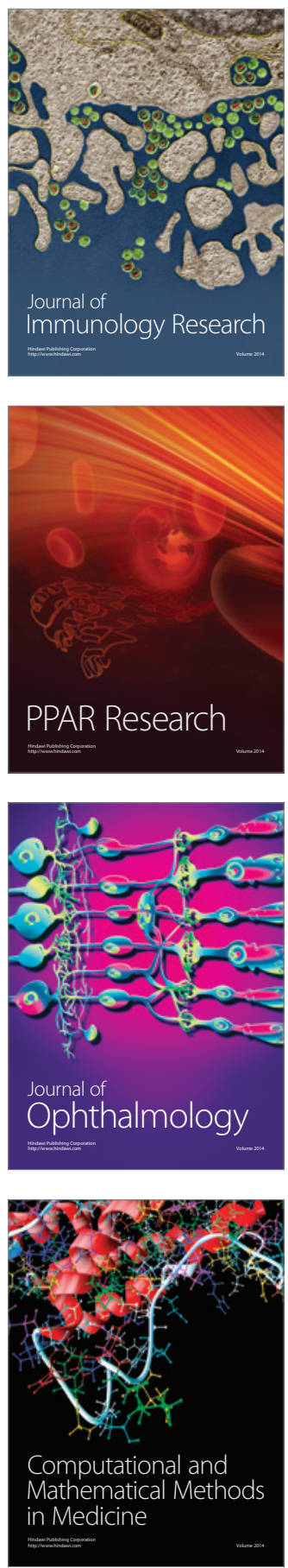

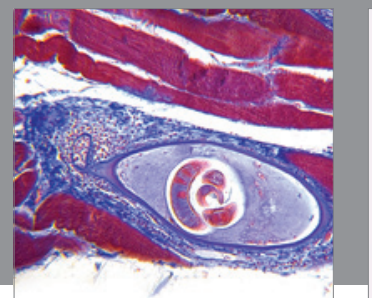

Gastroenterology

Research and Practice
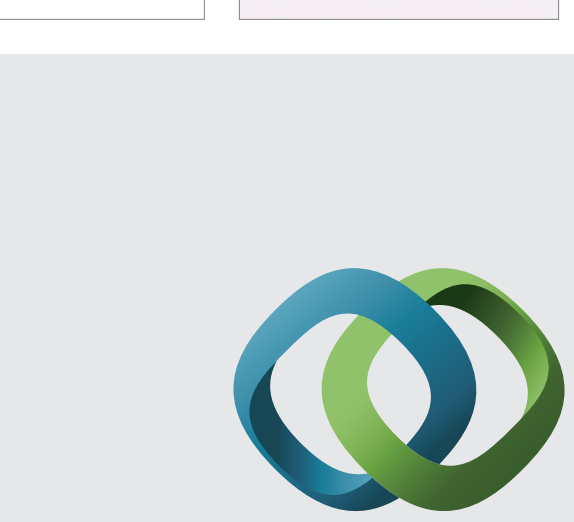

\section{Hindawi}

Submit your manuscripts at

http://www.hindawi.com

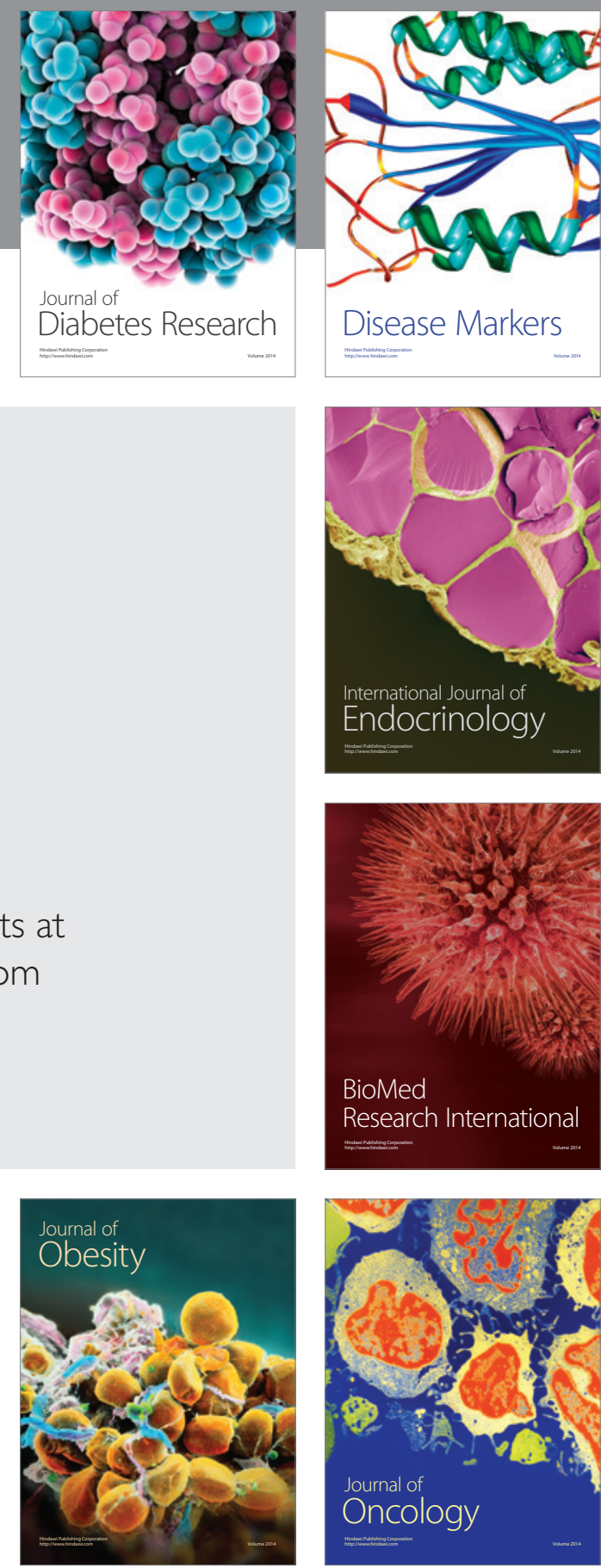

Disease Markers
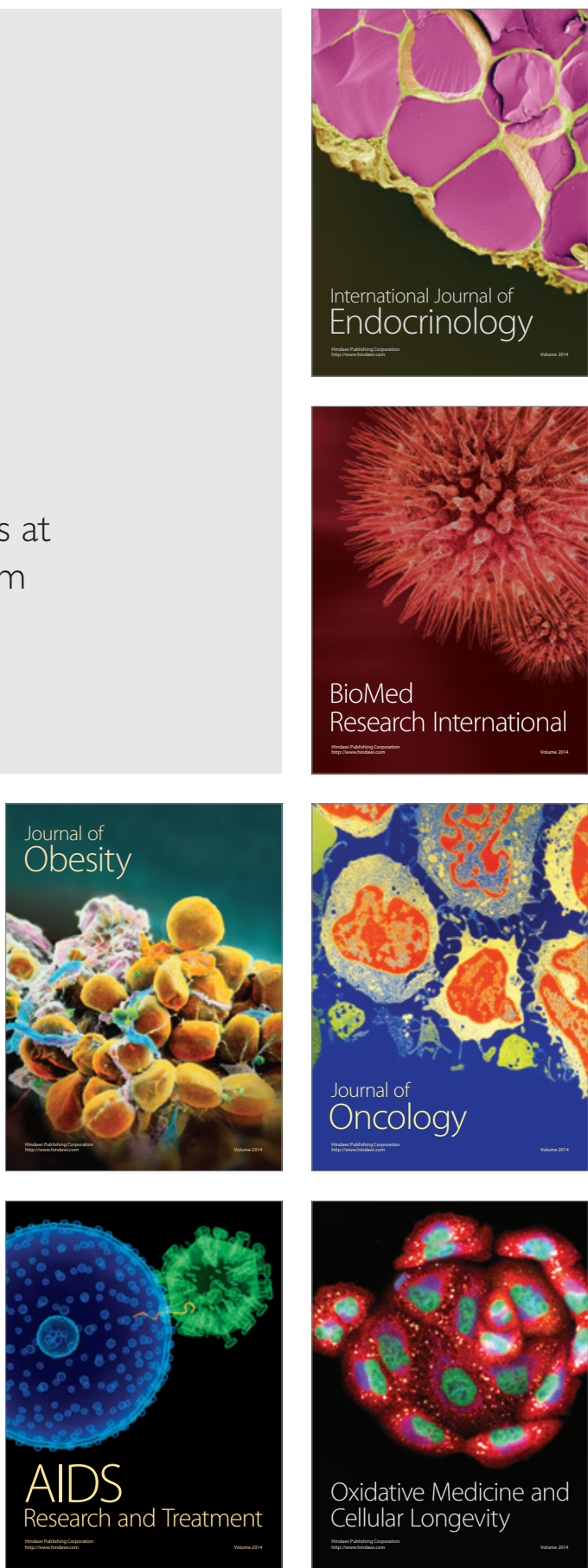